\title{
Lungfishes, like tetrapods, possess a vomeronasal system
}

\author{
Agustín González" ${ }^{*}$, Ruth Morona' ${ }^{1}$ Jesús M. López' ${ }^{1}$, Nerea Moreno ${ }^{1}$ and R. Glenn Northcutt ${ }^{2}$ \\ Department of Cell Biology, Faculty of Biology, University Complutense of Madrid, Madrid, Spain \\ 2 Laboratory of Comparative Neurobiology, Scripps Institution of Oceanography and Department of Neurosciences, School of Medicine, University of California, \\ San Diego, CA, USA
}

\section{Edited by:}

Javier DeFelipe, Cajal Institute, Spain

\section{Reviewed by:}

Alino Martinez-Marcos, Universidad de Castilla, Spain

Heather L. Eisthen, Michigan State

University, USA

${ }^{*}$ Correspondence:

Agustín González, Department of Cell Biology, Faculty of Biology, University

Complutense of Madrid, C/José

Antonio Novais 2, Madrid E-28040,

Spain.

e-mail:agustin@bio.ucm.es
The vomeronasal system (VNS) is an accessory olfactory system that in tetrapod vertebrates is composed of specific receptor neurons in the nasal organ and a set of centers in the forebrain that receive and relay the information consecutively towards the hypothalamus. Thus, only in tetrapods theVNS comprises a discrete vomeronasal (Jacobson's) organ, which contains receptor cells that are morphologically distinct from those of the olfactory epithelium and use different transduction mechanisms. The axons of the vomeronasal receptors in tetrapods project to the accessory olfactory bulb (AOB) in the rostral telencephalon. Secondary vomeronasal connections exist through the medial amygdala to the hypothalamus. Currently, the lungfishes are considered the closest living relatives of tetrapods. Here we show that the African lungfish, Protopterus dolloi, has epithelial crypts at the base of the lamellae of the olfactory epithelium that express markers of the vomeronasal receptors in tetrapods. The projections of these crypts allow us to identify an $\mathrm{AOB}$ on the lateral margin of the main olfactory bulb. The projections of this $\mathrm{AOB}$ reach a region that is topologically, hodologically, and immunohistochemically identical to the medial amygdala and could represent its homolog. Neurons of this putative medial amygdala were demonstrated to project to the lateral hypothalamus, as they do in tetrapods. All these features that lungfishes share with tetrapods indicate that lungfishes have the complete set of brain centers and connections involved in processing vomeronasal information and that these features were already present in the last common ancestor of lungfishes and tetrapods.

Keywords: accessory olfactory bulb, medial amygdala, lobe-finned fish, homology, evolution

\section{INTRODUCTION}

The vomeronasal system (VNS), or accessory olfactory system, is a discrete sensory system that consists of a peripheral vomeronasal organ, an accessory olfactory bulb (AOB), and the AOB's projections to distinct zones in the caudal telencephalon and from there to the hypothalamus (Halpern and Martínez-Marcos, 2003). The VNS comprises anatomical, physiological, and molecular features that differ from those of the main olfactory system, thus suggesting different behavioral functions (Halpern and Martínez-Marcos, 2003; Eisthen and Polese, 2007). It has long been believed that this accessory olfactory system exists only in tetrapods. The VNS was presumed to be specialized for detecting pheromones but it was proven that it responds to a variety of odorants with differing behavioral significance in all groups of tetrapods (Halpern and Martínez-Marcos, 2003; Baxi et al., 2006; Shepherd, 2006; Eisthen and Polese, 2007). Unlike the main olfactory system, the VNS may be specialized for detecting non-volatile molecules, although this broader hypothesis is still problematic (Baxi et al., 2006). As a strict morphological entity formed by the chain of structures from the nasal organ to the hypothalamus, the VNS has not been recognized in fishes (Grus and Zhang, 2006), but VNS-specific genes were recently identified in bony fishes, elasmobranches, and lampreys thus indicating that genetic components of the VNS-specific signal transduction pathway arose early in vertebrate evolution (Grus and Zhang, 2009). The tissue-specific expression patterns of these genes further indicate the existence of a possible VNS precursor in bony fishes (Hansen et al., 2004; Sato et al., 2005; Brennan and
Zufall, 2006; Grus and Zhang, 2006). In addition, the presence of a separate, accessory chamber or diverticulum of the nasal cavity containing a sensory epithelium that is histologically distinguishable from the olfactory epithelium present in the main chamber of the nasal cavity; and an $\mathrm{AOB}$ in the anterior telencephalon in larval and permanently aquatic amphibians challenged the idea that the VNS is an adaptation for air breathing (Eisthen, 2000). This prompted us to investigate lungfishes for the possible presence of specializations in the olfactory organ and distinct pathways within the central nervous system comparable to the VNS in tetrapods (Halpern and Martínez-Marcos, 2003).

Lungfishes or dipnoans are a monophyletic group of osteichthyan fishes (Schultze and Campbell, 1986). Together with the coelacanths, they represent the only living lobe-finned fishes, from the plethora that existed in the Devonian (Moy-Thomas and Miles, 1971; Lee et al.2006). The lungfishes occupy an interesting evolutionary niche, since they diverged from the vertebrate lineage after the divergence of most other fish lineages, such as that leading to the teleosts, but prior to the divergence of the amphibians. In addition, molecular phylogenetic studies favor the lungfishes as the closest living relatives of tetrapods (Meyer and Wilson, 1990; Meyer and Dolven, 1992; Hedges et al., 1993; Zaradoya et al., 1998; Tohyama et al., 2000; Brinkmann et al., 2004; Takezaki et al., 2004; Hallström and Janke, 2009). Only six species, belonging to three different genera are extant today in some rivers and swamps of Africa (Protopterus), South America (Lepidosiren), and Australia (Neoceratodus). The species Protopterus dolloi was used in this analysis. 
Considering the crucial position of lungfishes in a phylogenetic perspective, a wide series of immunohistochemical analysis was made in the olfactory organ, the olfactory bulbs and the telencephalon of Protopterus. The olfactory organ was labeled with antibodies against the guanosine- $5^{\prime}$-triphosphate (GTP)-binding protein subunits Go $\alpha$ and Gi $\alpha 2$ for the characterization of putative vomeronasal receptor cells. In addition, we have studied in the forebrain of the juvenile the pattern of distribution of important regulatory transcription factors and proteins useful for the delineation of brain territories. These were the transcription factors NKX2.1, Orthopedia (OTOP), and Islet1 (ISL1), which have been systematically analyzed in combination with the neuronal markers tyrosine hydroxylase $(\mathrm{TH})$, nitric oxide synthase (NOS), substance $\mathrm{P}$ (SP), and calbindin-D28k (CB). The choice of these molecules was based on previous results in other species of vertebrates in which they served to characterize distinct portions of the VNS (Halpern and Martínez-Marcos, 2003; Moreno and González, 2003, 2006, $2007 b, c)$. In addition, we incorporated a hodological approach by means of tract tracing with carbocyanines (DiI) to further asses the connections between the main components of the VNS.

\section{MATERIALS AND METHODS ANIMALS AND TISSUE PROCESSING}

For the present study, the brains and olfactory organs of 15 African lungfish Protopterus dolloi were used. The animals were juvenile or adult specimens obtained from authorized commercial suppliers and the original research reported herein was performed according to the regulations and laws of the European Union (86/609/ECC) and Spain (Royal Decree 223/1998) for the care and handling of animals in research. In all cases, prior to perfusion, the animals were deeply anesthetized in a $0.3 \%$ solution of tricaine methanesulfonate, pH, 7.4 (MS222, Sigma, St. Louis, MO, USA).

\section{IMMUNOCHEMISTRY}

The brain and nasal cavities of ten animals were used for immunohistochemistry. The animals, under anesthesia, were perfused transcardially with saline followed by $200 \mathrm{ml}$ of $4 \%$ paraformaldehyde in $0.1 \mathrm{M}$ phosphate buffer (PB; pH 7.4). The brains and olfactory organs were removed and kept in the same fixative for 1.5-3 h. Subsequently, they were immersed in a solution of $30 \%$ sucrose in $\mathrm{PB}$ for $5 \mathrm{~h}$ at $4^{\circ} \mathrm{C}$ until they sank, embedded in a solution of $20 \%$ gelatin with $30 \%$ sucrose in $\mathrm{PB}$, and then immersed in a $3.7 \%$ formaldehyde solution at $4^{\circ} \mathrm{C}$ for $8-10 \mathrm{~h}$. The brains were cut on a freezing microtome at $40 \mu \mathrm{m}$ in the transverse or sagittal plane, whereas the olfactory organs were cut horizontally, and sections were collected and rinsed in cold PB. From each brain or nasal cavity, four parallel series of free-floating sections were obtained that were then carried through the immunostaining protocol. This included incubation for $24-48 \mathrm{~h}$ at $4^{\circ} \mathrm{C}$ with the primary antibodies: rabbit anti-calbindin-D28k (diluted 1:1,000; Swant); sheep antiNOS (diluted 1:20,000; Dr. P.C. Emson), mouse anti-TH (diluted 1:1,000; Immunostar Inc.), rabbit anti-Goo (diluted 1:2,000; MBL), mouse anti- Gio2 (diluted 1:2,000; Upstate Biotech.), mouse antiISL1 (diluted 1:500; DSHB); rabbit anti-NKX2.1 (diluted 1:1,000; Biopat), rabbit anti-SP (diluted 1:1,000; Cambridge), and rabbit anti-OTP (diluted 1:1,000; Dr. F. Vaccarino). All primary antibodies were diluted in 5-10\% normal serum in PB with $0.1 \%$ Triton X-100 (Sigma) and 2\% bovine serum albumin (BSA, Sigma). The serum used in each case corresponded with the species in which the secondary antibody was raised.

Subsequently, the sections were incubated for $2 \mathrm{~h}$ at room temperature with fluorescently tagged secondary antibodies (Molecular Probes). They were goat anti-rabbit Alexa 594 diluted 1:500, goat anti-mouse Alexa 488 diluted 1:500, or donkey anti-sheep rhodamine diluted 1:100. After rinsing, the sections were mounted on glass slides and coverslipped with Vectashield (Vector, Burlingame, CA, USA). Images were acquired with a digital camera (Olympus DP70) and contrast and brightness of the photomicrographs were adjusted in Adobe PhotoShop 7.0 (Adobe Systems, San Jose, CA, USA).

All the primary antibodies have been previously tested in different vertebrates, particularly in amphibians, where they were used as territorial markers (Marín et al., 1998; González et al., 2002a,b; Brox et al., 2003; Moreno and González, 2003, 2004, 2005a, 2007a,b; Morona and González, 2008). Furthermore, most of them were recently used in the study of the telencephalic regionalization of lungfishes (González and Northcutt, 2009).

\section{Double immunohistochemistry}

To study the co-localization or co-distribution of two proteins in the same sections, different two-step protocols for immunohistofluorecence were used with antibody cocktails as follows: pairs of primary antibodies developed one in rabbit and one in mouse were used in a cocktail, with the same dilution and characteristics as described above for the single labeling (combinations: $\mathrm{CB} / \mathrm{TH}$, OTP/ISL1, CB/Go $\alpha$, and NKX2.1/ISL1). The second incubation was conducted as for single labeling but with a secondary cocktail of Alexa 594-conjugated goat anti-rabbit (Molecular Probes) and Alexa 488-conjugated goat anti-mouse (Molecular Probes). After rinsing the sections were mounted on glass slides and coverslipped with Vectashield (Vector).

\section{ANTIBODY CHARACTERIZATION}

General controls for the immunohistochemical reaction included: (1) staining some selected sections with preimmune rabbit serum; (2) controls in which either the primary and/or the secondary antibody was omitted. In all these negative controls the immunostaining was eliminated. The specificity of the antibodies used has been assessed by the companies of manufacturer, and they recognize homologous across many vertebrate species. Because the actual molecules have not been isolated and characterized in lungfishes, it is possible that the immunohistochemical techniques used might result in non-identical labeling in lungfishes. However, the selected primary antibodies yielded patterns of staining in lungfishes that are consistent with those in many other vertebrates, thus strongly supporting their specificity in lungfishes also.

We used antibodies directed against mammalian forms of G-proteins ( $\mathrm{Go} \alpha$ and Gi $\alpha 2$ ) to assess the tissue distribution of these forms in lungfish. After preabsorption with the corresponding peptides supplied by Santa Cruz Biotechnology, no labeling appeared for the two antibodies. Western blots of G-proteins from tissue of Protopterus olfactory organ and brain were accomplished. Both Goo and Gi 2 antisera reacted with a major band of about 
40-43 kDa in the Protopterus tissues in accordance with mouse tissue brain and goldfish (specification by the commercial company Upstate biotechnology, and in Hansen et al., 2004).

The specificity of the polyclonal antiserum anti-CB used in this study was assessed by the commercial company (Swant). The antiserum was produced against recombinant rat $\mathrm{CB}$ and cross-reacts with CB of many other species, including Protopterus (González and Northcutt, 2009; Morona and González, 2009).

Thyroid transcription factor 1 (known as TTF-1, NKx2.1, or T/ EBP) is a homeodomain-containing transcription factor expressed in thyroid and lung epithelium and in restricted regions of the fetal brain (Lazzaro et al., 1991). The Nkx2.1 antiserum was raised against a synthetic peptide consisting of amino acids 110-122 from the amino terminus of the protein. It gives a specific nuclear staining on TTF- 1 containing cells in tissues of all vertebrates tested. In previous studies the same antibody has been used in diverse species to characterize forebrain regions, as in Protopterus (Marín et al., 2000; González et al., 2002a,b; Carrillo and Doupe, 2004; Bachy and Rétaux, 2006; Métin et al., 2007) with comparable results, supporting the conservation of this transcription factor in the evolution.

The anti-Isl1 monoclonal antibody (Ericson et al., 1995) was developed by Dr. Jessell (Columbia University; New York, NY, USA) and is supplied by the Hybridoma bank (Developmental Studies Hybridoma Bank, University of Iowa, Iowa City, IA, USA). It has recently been used and tested in many species with comparable results (see data sheet DSHB), and in immunohistochemical analysis of the forebrain, including Protopterus (Métin et al., 2007; Moreno et al., 2008; González and Northcutt, 2009). The Islet1 antibody recognizes the C-terminal portion of rat Islet1 (the antigen used was a recombinant protein made in E. coli, containing the amino acid range cited).

OTP is a highly conserved homeodomain-containing factor that is transcribed during embryonic development in a segment-like expression pattern mainly including hypothalamic areas (Puelles and Rubenstein, 2003). The specificity of the OTP antiserum was previously described (Lin et al., 1999). The highly conserved 69-bp region at the $\mathrm{C}$-terminal domain is the sequence used to prepare the OTP antibody. The polyclonal antiserum directed against the C-terminal sequence of the OTP predicted protein product was raised against a 13-amino acid sequence, RKALEHTVSMSFT, which is completely conserved in the species studied by BLAST. The utility of this antiserum for the study of the forebrain regionalization in diverse vertebrates has been shown in previous studies (Bardet et al., 2008; González and Northcutt, 2009).

The $\mathrm{TH}$ antibody was raised against denatured $\mathrm{TH}$ from rat pheochromocytoma, and its specificity was corroborated by Western blot analysis in rat, mouse, ferret, feline, and Aplysia, in which it selectively labels a single band at approximately $62 \mathrm{kDa}$. The antibody recognizes an epitope in the midportion of the $\mathrm{TH}$ molecule, where extensive species homology exists, and has been used to analyze the catecholaminergic systems in many vertebrate classes, from lamprey through primates (see Smeets and González, 2000) including lungfishes (González and Northcutt, 2009).

The polyclonal NOS antiserum was raised in sheep against recombinant rat NOS, and its specificity has been previously described (Herbison et al., 1996). Antibody specificity against neuronal NOS was assessed by liquid phase adsorption experiments (Simonian and Herbison, 1996). In addition, the specificity of the antiserum for detection of NOS was warranted by the observation of a staining pattern that was identical to that in previous reports in which it matched the NADPH-diaphorase histochemical reaction (González et al., 1996; Smeets et al., 1997).

\section{NADPH-DIAPHORASE (NADPHd) HISTOCHEMISTRY}

In this protocol, free-floating sections were incubated in a medium containing $1 \mathrm{mM}$ b-NADPH, $0.8 \mathrm{mM}$ nitroblue tetrazolium, and $0.06 \%$ Triton X-100 (Sigma) in $0.1 \mathrm{M} \mathrm{PB}, \mathrm{pH} \mathrm{7.6}$, at $37^{\circ} \mathrm{C}$ for $1-2 \mathrm{~h}$. After incubation, the sections were rinsed thoroughly in $\mathrm{PB}$ and, subsequently, they were then mounted on glass slides from a solution of $0.25 \%$ gelatin and, after dehydration, the slides were coverslipped with Entellan (Merck).

\section{TRACT TRACING WITH Dil}

To establish the connections of the AOB with caudal (amygdaloid regions) or the olfactory organ, as well as the connections between the hypothalamus and the amygdala, applications of the lipophilic carbocyanine tracer DiI (Molecular Probes) were used in five animals. In the case of the $\mathrm{AOB}$, calcium binding protein calbindin-28kD (CB) immunohistochemistry was first conducted in the isolated forebrain, as whole mount, as described above. Subsequently, a small crystal of DiI was placed on the tip of a sharpened insect pin, which was directly inserted into the bulbar region labeled for $\mathrm{CB}$, under a stereomicroscope equipped with epifluorescence. In three animals, the application into the accessory bulb was conducted on the dissected brains in which the connection with the olfactory organ was maintained. In the two cases of the hypothalamic applications, larger crystals were used that were placed in the infundibular hypothalamus, including lateral, dorsal and ventral regions. In all cases, after DiI application to the brain, the area was covered with $20 \%$ gelatin in order to prevent the crystals from dislodging. The brains were returned to a $4 \%$ buffered paraformaldehyde solution and stored in the dark for $2-4$ weeks in frequently renewed fresh fixative at $37^{\circ} \mathrm{C}$. However, the brains with hypothalamic applications were maintained for 6-10 weeks to allow better staining of retrogradely labeled cells. After the transport period, transverse sections (50- $\mu \mathrm{m}$ thick) were obtained on a vibratome and mounted on gelatin-coated slides. Sections were then coverslipped in Fluoromount (Southern Biotech), a water-soluble mounting medium, and examined and photographed as above.

\section{RESULTS}

The multiple immunohistochemical detections conducted either in single or in combined procedures will be described for the main centers of the VNS, i.e. the olfactory organ, the olfactory bulbs and the region of the caudal telencephalon where the putative vomeronasal amygdala is located. The latter has been termed medial amygdala (MeA) for comparison with tetrapod vertebrates (Moreno and González, 2003, 2006, 2007b,c; Northcutt, 2008, 2009; González and Northcutt, 2009). It is to be noted that the distinct immunohistochemical stainings were consistent from animal to animal. Immunohistofluorescence was chosen because of its high sensitivity 
and the possibility of conducting double and triple stainings on the same section, which is useful to ascertain the actual position of each particular region.

\section{THE OLFACTORY ORGAN}

The nasal cavity of Protopterus contains a series of suspended lamellae projecting from a midline raphe (Figure 1A). Each lamella is furrowed with receptor grooves covered with the olfactory epithelium. Between adjacent lamellae, epithelial crypts or acini are formed and show a complex morphology (Figures 1B,C). The olfactory epithelium is labeled with antibodies against the GTPbinding protein subunit Goo (Figures 2A,B,D), and such labeling is also present in the small epithelial crypts that lie at the base of the lamellae and contain receptor cells (Figures 2A-C,E). Within the crypts, two distinct parts are observed, one part with several cell layers and intensely reactive for Go $\alpha$ and another formed by elongated cells with long apical cytoplasm extending towards the surface and Goo-negative (Figures 2E and 3). The sensory epithelium on the surface of the lamellae is also labeled by antibodies against the Gio2 subunit (Figure 3A), but the basal crypts are not labeled (Figures 3A,D).

Notably in Protopterus, the calcium binding protein calbindin$28 \mathrm{kD}(\mathrm{CB})$ is expressed exclusively in the sensory cells of the epithelial crypts, i.e. in those cells that express Goo, but not in the epithelium of the lamellae (Figures 4A-I). The axons from the $\mathrm{CB}$-positive cells converge in the lateral part of the olfactory nerve, without forming a separate branch (Figure 4C), and terminate in a particular set of glomeruli labeled in the lateroventral part of the large olfactory bulb (Figures 5A,B).

\section{ACCESSORY OLFACTORY BULB (AOB)}

The olfactory bulbs of Protopterus are large sessile structures located in the dorsal region of the anterior portion of the telencephalon and are provided with large ventricular cavities. They present a laminar structure as in all vertebrates. The presence of an $\mathrm{AOB}$ is not anatomically distinct and it cannot be assessed with the use of histological stainings that have helped its identification in other vertebrates. Thus, NADPHd staining reveals specifically the glomerular layer of the olfactory bulbs but does not allow the recognition of an AOB (Figure 5C). However, the CB-positive axons of the cells labeled in the epithelial crypts terminate in a particular set of glomeruli labeled in the lateroventral part of the large main olfactory bulb (Figures 5A,B). This specific location, is identified here as the putative AOB of Protopterus, and it also shares other common features with the AOB's of tetrapods, such as the arrangement of catecholaminergic cells in the internal granule cell layer (Figures 5A,B).

To further support the existence of an AOB in Protopterus, we analyzed efferent projections of this area by means of tract tracing with the carbocyanine dye DiI (Figures 5D-I). Given the superficial location of the $\mathrm{AOB}$ in the brain, in this series of experiments $\mathrm{CB}$ immunohistochemistry was first performed in toto to localize the precise position of the labeled glomeruli in the ventrolateral aspect of the olfactory bulb (Figure 5D). Under control with the fluorescence microscope, the DiI crystals were placed in the AOB (Figures 5E,F). These applications revealed that axons leaving the $\mathrm{AOB}$ course in the lateral aspect of the lateral pallium through most of the length of the hemisphere and converge in a distinct fiber bundle that turns and arborizes in a zone of the caudal telencephalon,
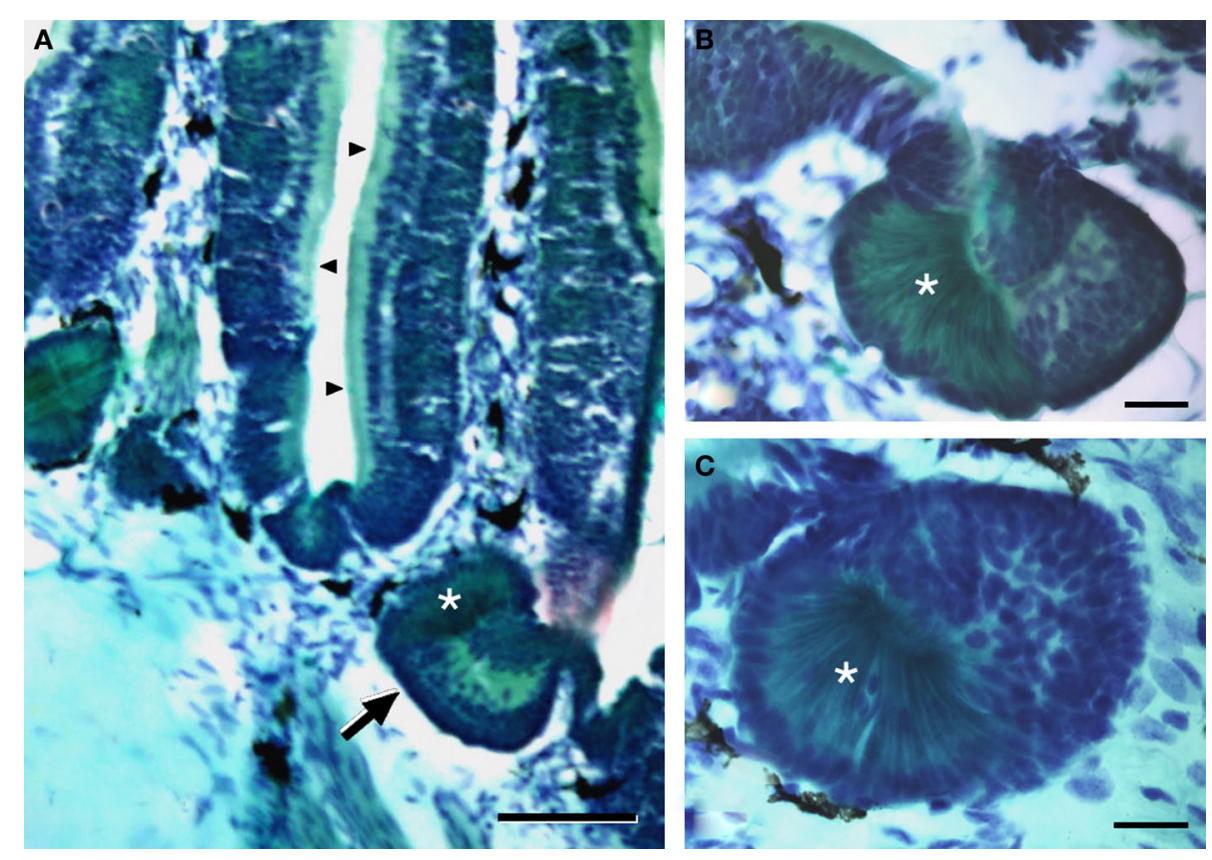

FIGURE 1 |The olfactory organ of Protopterus contains a series of suspended lamellae and epithelial crypts that lie at the base of the lamellae. (A) Histological sections of Masson's trichromic stain of the olfactory organ illustrating the olfactory lamellae with the sensory epithelium (arrowheads) and the crypts at the base (arrow). (B,C) High magnification of two basal crypts showing the two distinct parts that constitute the acini; the asterisks mark the distinct part of the crypt formed by elongated cells with basal nuclei and a narrow apical cytoplasm. Scale bars $=200 \mu \mathrm{m}(\mathbf{A})$ and $50 \mu \mathrm{m}(\mathbf{B}, \mathbf{C})$. 

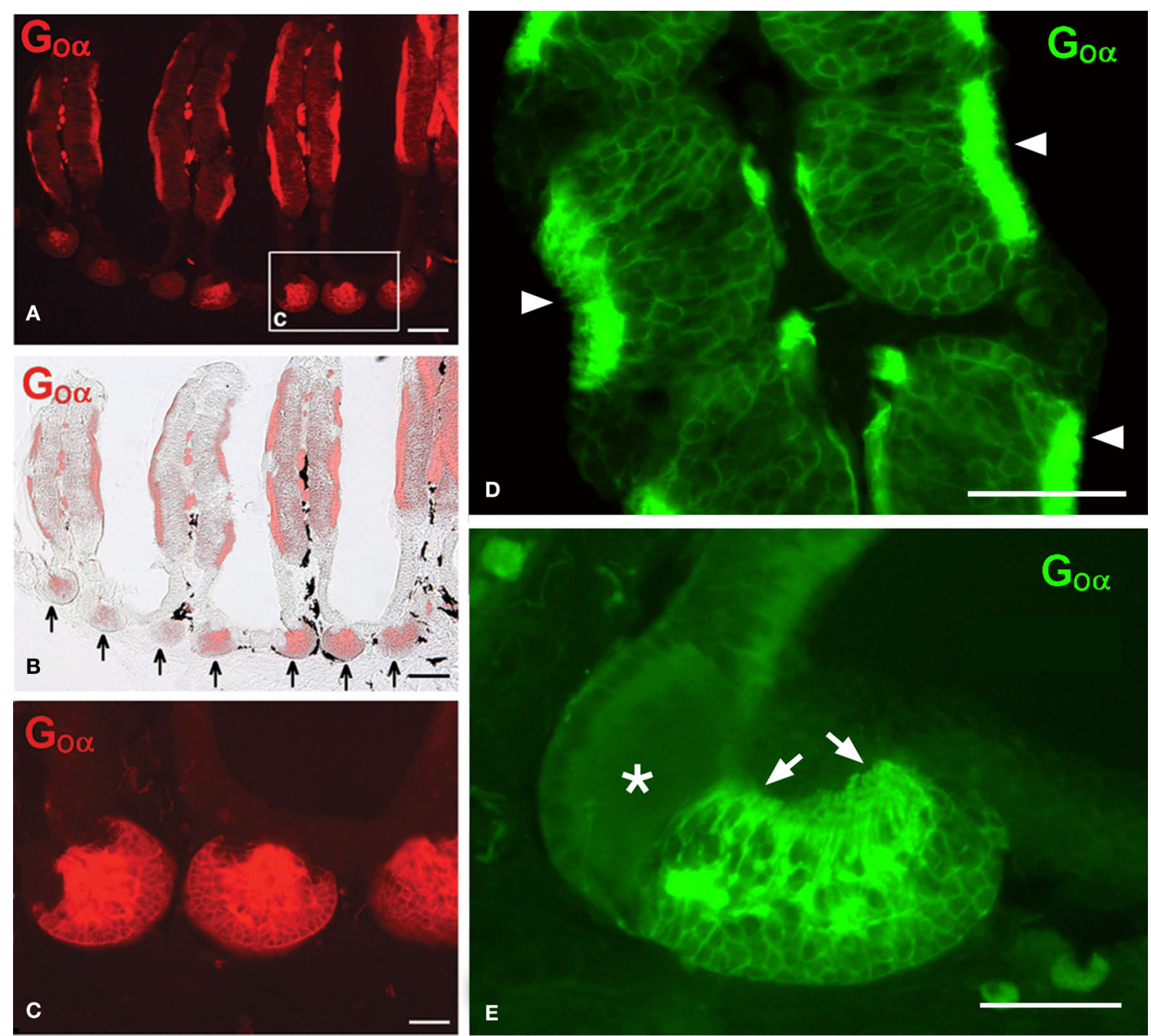

FIGURE 2 |The olfactory epithelium in the lamellae and the crypts contains cells immunoreactive for Goo. (A,B) Fluorescence microscopy (A) and Goo immunoreactivity combined with light microscopy (B) showing Goo immunoreactivity in the olfactory epithelium and in the epithelial crypts at the base of the lamellae (arrows). (C) Higher magnification of the area indicated in a.
(D) Detail of receptor grooves in a lamella showing the particularly intense Go $\alpha$ immunoreactivity at the surface (arrowheads). (E) Detail of a crypt showing a characteristic mixed crypt with Goo immunoreactivity only in one part and mainly in the apical processes towards the surface (arrows; asterisk marks the non-reactive part of the crypt). Scale bars $=200 \mu \mathrm{m}(\mathbf{A}, \mathbf{B})$ and $100 \mu \mathrm{m}$ (C-E). just rostral and dorsal to the preoptic region (Figures $\mathbf{5 G - I}$ ). By comparison with the equivalent region in the caudal telencephalon that receives the direct projection from the AOB in amphibians, we termed this region medial amygdala $(\mathrm{MeA})$, which would represent the vomeronasal amygdala of lungfishes.

In another set of experiments, DiI was similarly applied to the AOB in brains in which the connection with the nasal organ was maintained. Retrogradely labeled cells were consistently observed in the basal crypts (Figure 5J) but not in the receptors of the lamellae.

\section{THE MEDIAL AMYGDALA (MeA)}

Immunohistochemical and hodological features were investigated in the MeA of Protopterus to evaluate the possible homology of this region with the MeA of tetrapods. First, the patterns of distribution of three transcription factors (OTP, ISL1, and NKX2.1) were analyzed. It was demonstrated that the MeA was the only region within the telencephalon of Protopterus that expresses the homeodomain transcription factor OTP (Figures 6A,B). In addition, the expression of the territorial transcription factors ISL1 and NKX2.1 showed that this area is rich in cells that expressed ISL1 and almost totally lacks cells labeled for NKX2.1 (Figures 6C,D). Furthermore, other immunohistochemical features that characterize the MeA in tetrapods, such as substance $\mathrm{P}$ and nitric oxide synthase immunoreactivity, were corroborated in Protopterus (Figures 6E,F).

In tetrapods, the next link in the central vomeronasal pathways is the projection of information from the MeA to the lateral hypothalamus. Thus, to demonstrate this connection in the lungfish, we analyzed retrograde DiI tracing from the hypothalamus in Protopterus and found that substantial numbers of cells in the region identified as the MeA do, indeed, project to the hypothalamus (Figure 6G). 

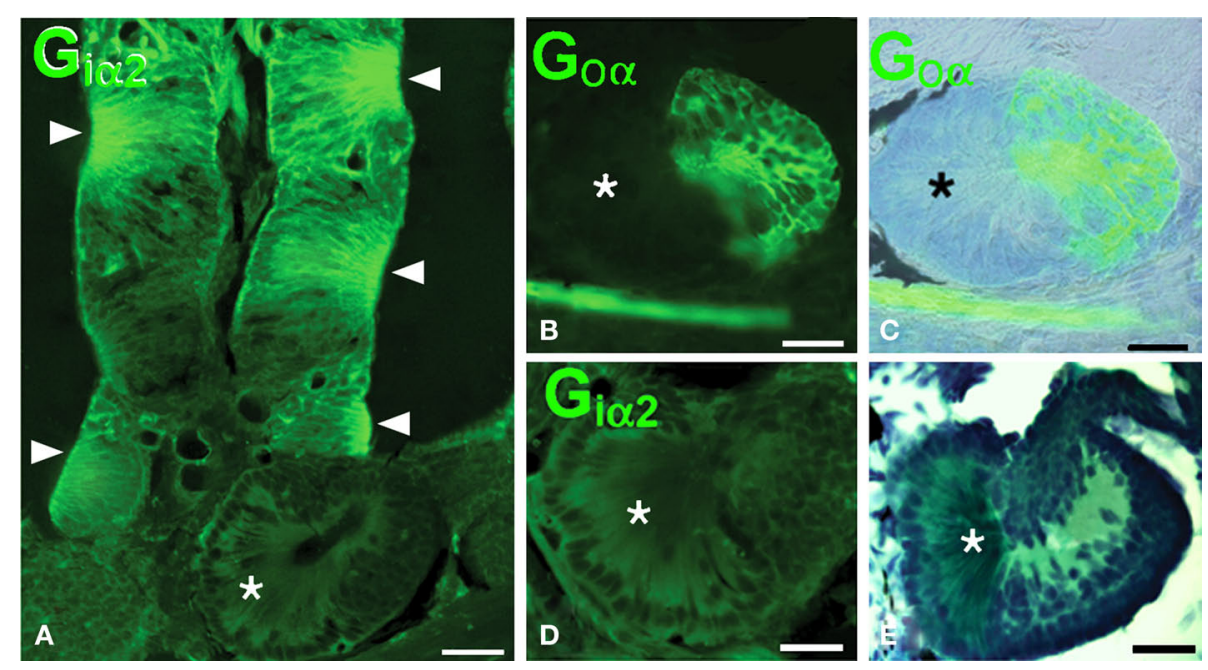

FIGURE 3 |The olfactory epithelium of the lamellae is Gi $\alpha 2$ - immunoreactive but the crypts only show Go $\alpha$-immunoreactivity. (A) Gi $\alpha 2$ immunoreactivity in the lamellar epithelium (arrowheads) and lack of reactivity in the basal crypts (asterisk). (B-D) The basal crypts are mixed structures with a Go $\alpha$-positive part (B,C) that is Gio2-negative (D) and a distinct part that lacks both reactivities (asterisks; $\mathbf{E}$, Masson's trichromic staining). Scale bars $=200 \mu \mathrm{m}$ (A) and $100 \mu \mathrm{m}$ (B-E).
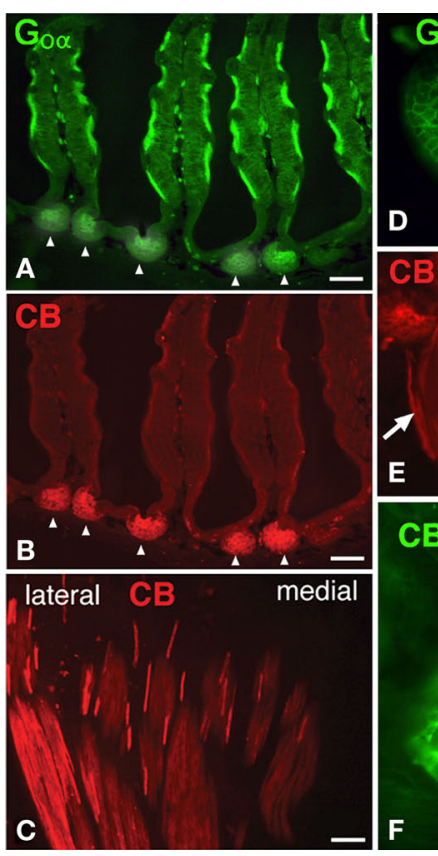
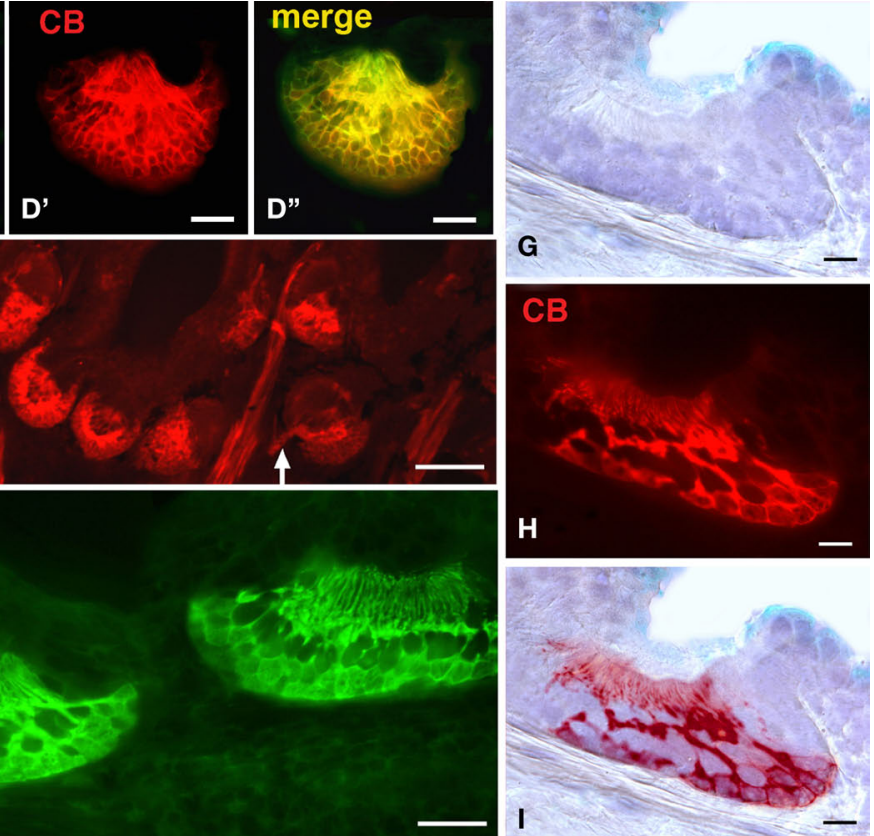

FIGURE 4 |The crypts are distinctly labeled with anti-calbindin antibodies. $(\mathbf{A}, \mathbf{B})$ As observed in the same doubly labeled section, only the crypts are CB-immunoreactive. (C) Axons from the CB-positive cells course separately from the olfactory organ and collect at the lateral aspect of the olfactory nerve. (D-D"), Higher magnification of a crypt double labeled for Go $\alpha$ (D), CB (d') and the merge image ( $\left.\mathbf{D}^{\prime}\right)$. (E) Image of numerous CB-immunoreactive crypts and the labeled axons (arrows). (F) High magnification of two labeled crypts. (G-I) Detail of a crypt stained for normal bright field microscopy (F) and CB-immunofluorescence (G), overlapped figure shows the location of the immunoreactive cells $(\mathbf{H})$. Scale bars = $200 \mu \mathrm{m}$ (A,B,E), $100 \mu \mathrm{m}$ (C), $50 \mu \mathrm{m}$ (D-D",F) and $25 \mu \mathrm{m}$ (G-I).

\section{DISCUSSION}

In the present study we have demonstrated that lungfishes possess all components of the accessory system relating specific olfactory information through a chain of brain centers (Figure 7) fully comparable to the components of the VNS in tetrapods.
Earlier anatomical studies suggested that lungfishes possess a precursor of the vomeronasal organ and a nerve connecting that organ with a distinct telencephalic region in the medial portion of the hemisphere, tentatively termed the AOB, in accordance with the primary brain center that receives vomeronasal 

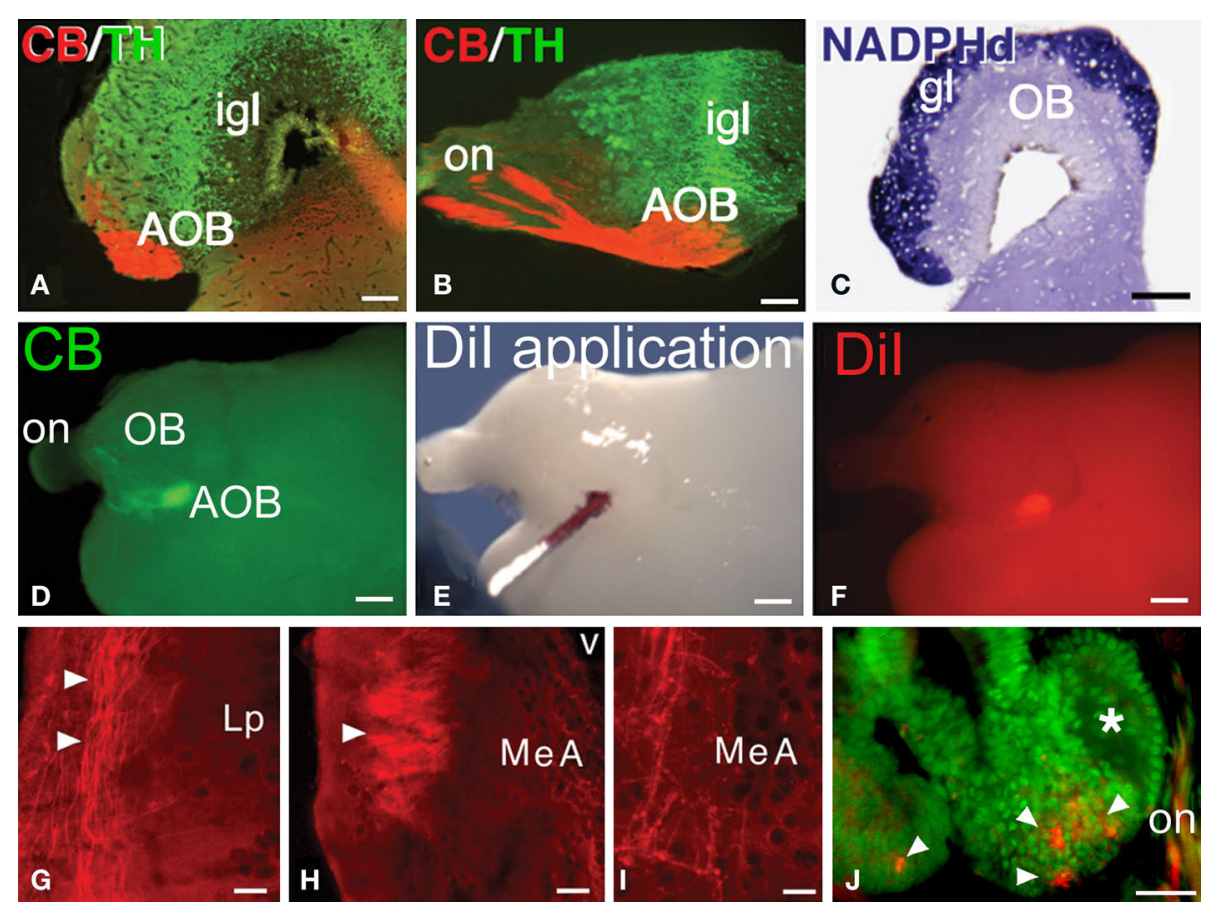

FIGURE 5 |The AOB and the pathway to the medial amygdala. (A-C) The CB-positive axons in the lateral aspect of the olfactory nerve (on) reach a subset of glomeruli in the $\mathrm{AOB}$, in the ventrolateral part of the bulb ( $\mathbf{A}$, transverse section, lateral is to the left; $\mathbf{B}$, sagittal section, rostral is to he left). The glomerular layer ( $\mathrm{gl}$ ) on the surface of the olfactory bulb is completely labeled for NADPH-diaphorase (C). (D-F) Following CB-immunohistochemistry in the whole-mount brain (D) to localize the AOB, crystals of Dil were applied (E,F). (G-I) Transverse sections through the left hemisphere, lateral is to the left, in which the anterogradely labeled fibers from the application site in the left AOB were followed through the lateral pallium (G) and seen to form a tract that at caudal telencephalic levels forms a neuropil and ends as varicose fibers in the MeA (H,I). (J) After a small injection of Dil into the AOB, retrogradely labeled cells were only observed in the basal crypts (arrowheads). Abbreviations: AOB, accessory olfactory bulb; gl, glomerural layer; igl, inner granule cell layer; Lp, lateral pallium; MeA, medial amygdala; OB, main olfactory bulb; on, olfactory nerve. Scale bars $=200 \mu \mathrm{m}$ (A-C), $400 \mu \mathrm{m}$ (D-F), $100 \mu \mathrm{m}$ (G-J). information in tetrapods (Rudebeck, 1944; Schnitzlein and Crosby, 1967). However, these observations were not supported in subsequent studies using more modern techniques (Derivot, 1984; Reiner and Northcutt, 1987; von Bartheld et al., 1988; Northcutt, 2008), and thus there was considered to be no evidence that lungfishes possess a vomeronasal organ or nerve, nor any indication of vomeronasal relay centers such as exist in the brains of tetrapods.

\section{VOMERONASAL ORGAN AND AOB}

In the lamellae of the nasal cavity of Protopterus the olfactory epithelium consists of ciliated and, more abundant, microvillar olfactory receptor neurons and a separate structure that could represent the vomeronasal organ is not observable (Derivot, 1984). However, we have found special epithelial crypts that contain receptor cells labeled for the Goo-protein (as the epithelium in the lamellae) but lack Gio2 containing cells.

In tetrapods, the vomeronasal receptors are generally microvillar cells that are sequestered in a discrete organ (Jacobson's organ), separated from the main olfactory epithelium, which contains ciliated receptor neurons. However, the correlation between receptor cell morphology and olfactory or vomeronasal function is not strict in all tetrapods (Eisthen and Polese, 2007). Two distinct families of receptors have been identified in vomeronasal sensory neurons in mammals: vomeronasal type 1 receptors (VR1) and vomeronasal type 2 receptors (VR2), both of which encode G-protein-coupled seven-transmembrane proteins (Halpern and Martínez-Marcos, 2003). The VR1 and VR2 receptors are expressed in distinct sets of neurons, share little sequence homology and are coupled to different signaling molecules (Takigami et al., 2004; Grus and Zhang, 2006) - the VR1 to the Gio2-protein and the VR2 to the Goo-protein - and they are thought to have an ancient evolutionary origin (Frontini et al., 2003; Grus and Zhang, 2009).

The distribution of multiple VR1 and VR2 genes in most jawed vertebrates, as suggested by comparative genomic analysis, supports their presence in a common ancestor of fishes and tetrapods (Grus and Zhang, 2006). In addition, the expression of various G-proteins in their sensory neurons appears to be a feature of vertebrate olfactory systems (Frontini et al., 2003). The segregation of olfactory and vomeronasal receptors seen in mammals, however, is not as strictly defined in other tetrapods. In the clawed frog, Xenopus laevis, for example, olfactory receptors are expressed in the main olfactory epithelium, and VR2 receptors are restricted to the vomeronasal organ (Hagino-Yamagishi, et al., 2004), whereas G-protein expression indicates that VR1 receptors are not expressed in the vomeronasal organ, but rather are found in the main olfactory epithelium (Date-Ito et al., 2008). Our observations suggest that VR1 and VR2 

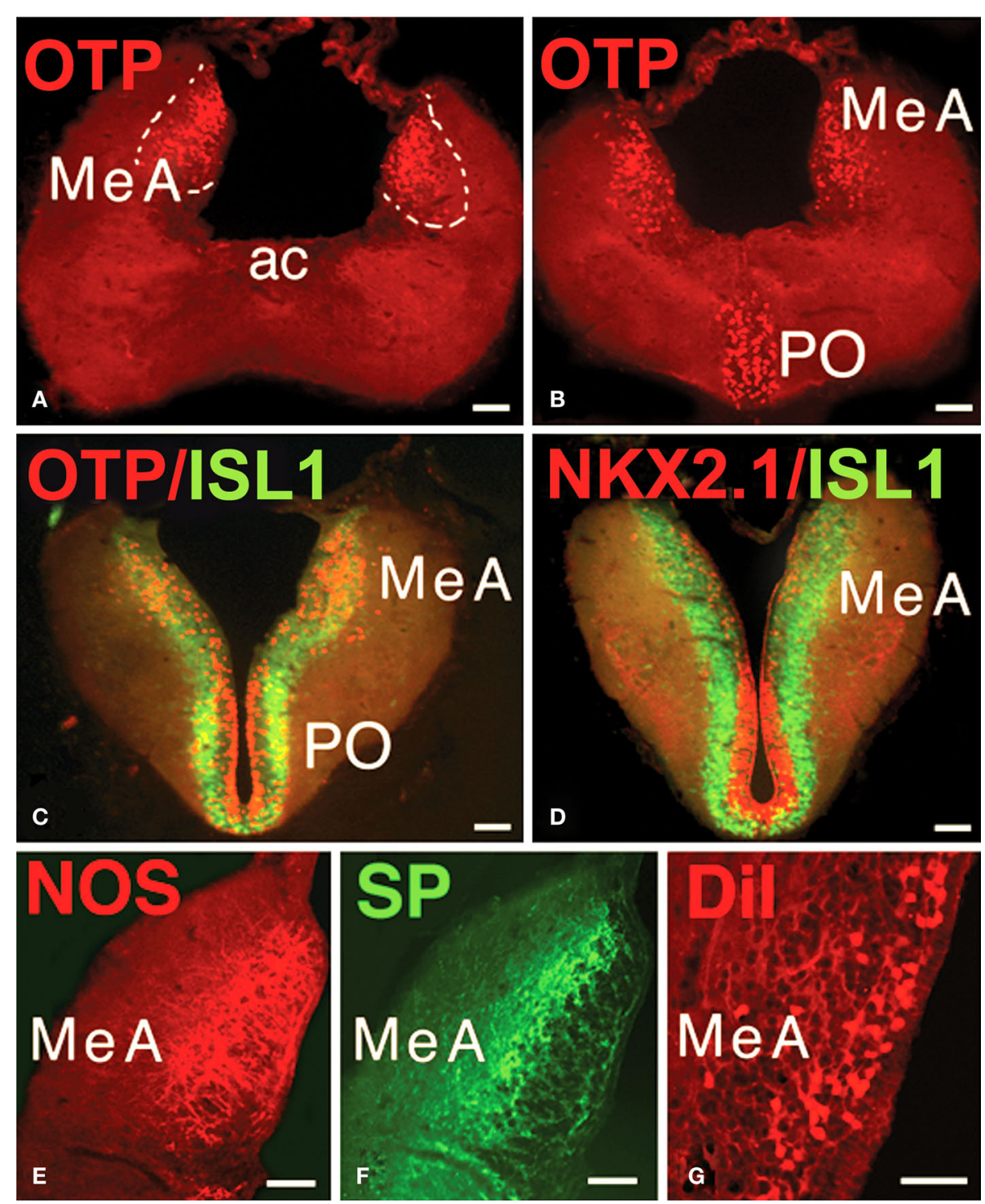

FIGURE 6 | Characterization of the MeA. (A,B) The MeA can be identified by its specific OTP-immunoreactivity. (C,D) The presence of ISL1-immunoreactivity and the virtual lack of NKX2.1 labeling characterize the MeA. (E,F) The distinct distribution of NOS and SP immunoreactive structures identifies the MeA.
(G) Retrogradely labeled cells in the MeA after Dil application to the lateral hypothalamus. All photographs correspond to transverse sections and in (E-G) only the left side is shown. Abbreviations: ac, anterior commissure; MeA, medial amygdala; PO, preoptic area. Scale bars $=200 \mu \mathrm{m}$. receptors (Go $\alpha$ and Gi $\alpha 2$ containing cells) in lungfishes are distributed in the epithelium of the lamellae, whereas only VR2 receptors (Goo-expressing cells) are located in the epithelial crypts.

In the case of fishes, it was first demonstrated that genetic components of the VNS signal transduction pathway are found in teleost fish, in addition to tetrapods (Grus and Zhang, 2006) and it was proposed that the VNS precursor (only considering the receptor cells in the nasal chemosensory system) existed in teleosts and that its evolutionary origin predated the separation between teleosts and tetrapods. However, a subsequent study conducted to determine when the genetic components of the VNS originated revealed that components of the vomeronasal signaling pathway, are present in the sea lamprey genome, and are expressed in the olfactory organ, revealing that the genetic components of the present-day VNS existed in the common ancestor of all extant vertebrates (Grus and Zhang, 2009).

Anatomically, all fishes investigated to date lack both a discrete vomeronasal organ and accessory bulb, but in the goldfish was shown that the olfactory sensory neurons that bear cilia, like mammalian olfactory receptor neurons, express receptor genes similar to those that characterize the mammalian olfactory epithelium (Hansen et al., 2004). A second class of olfactory sensory neurons that bear microvilli, and therefore resemble mammalian vomeronasal receptor neurons, expresses receptor genes that characterize the mammalian vomeronasal epithelium (see Eisthen, 2004). However, Hansen et al. (2004) 


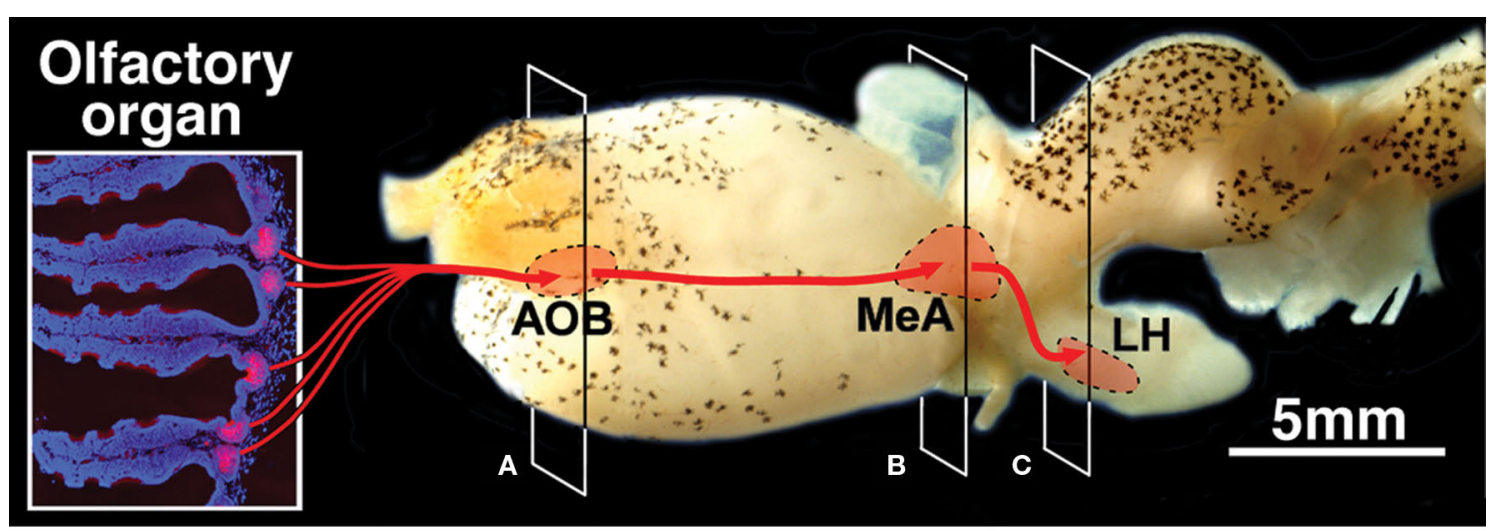

A

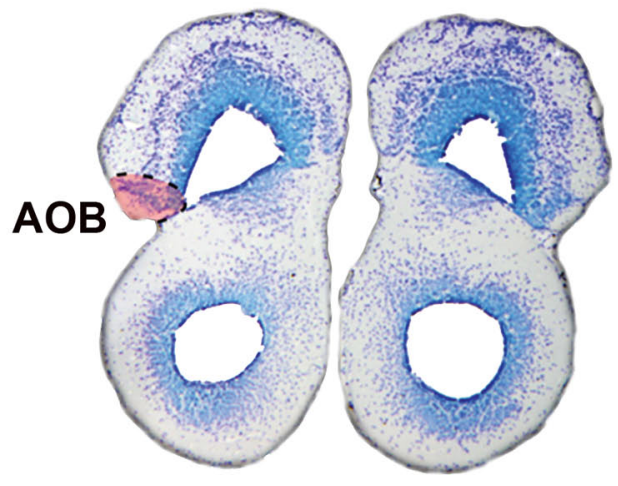

B

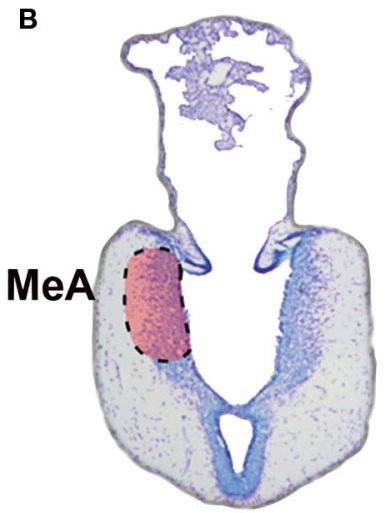

C

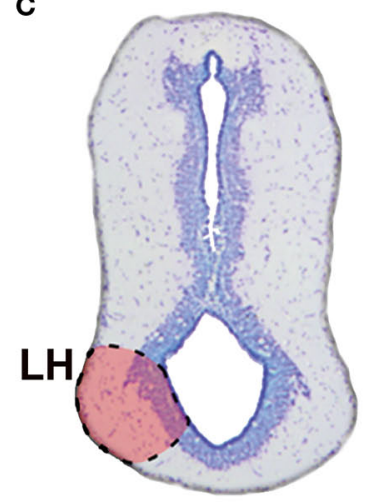

FIGURE 7 | Summary diagram of the vomeronasal system in lungfishes. (A-C) Transverse Nissl stained sections at the levels indicated on the lateral view of the brain showing the location of its three relay centers in the accessory olfactory bulb (AOB), the medial amygdala (MeA) and the lateral hypothalamus (LH).

clearly stated that attempts to ascribe specific functions to the olfactory or vomeronasal system, or to morphological classes of receptor cells within these systems, have been frustrating and contradictory results have been reported (Thommesen, 1983; Erickson and Caprio, 1984; Zippel et al., 1997; Sato and Suzuki, 2001; Hansen et al., 2003). Subsequently, a study on transgenic zebrafish (Sato et al., 2005) demonstrated that the olfactory bulbar projections of the neurons in the olfactory epithelium that express vomeronasal-type genes reach the lateral aspect of the olfactory bulb and are segregated from those that express olfactory-type genes.

A specific feature in Protopterus is the exclusive labeling for $\mathrm{CB}$ of the receptor cells in epithelial crypts, whose projections could be distinctly followed and traced in the olfactory nerve to terminate in a particular region of the ventrolateral aspect of the olfactory bulb. This specific location, which was not distinctly labeled by tract tracing techniques for olfactory (von Bartheld et al., 1988) or nitric oxide synthase reactivity (Schöber et al., 1994; present results), is therefore identified here as the putative $\mathrm{AOB}$ of lungfishes. Comparatively, vomeronasal receptor cells are immunoreactive for $\mathrm{CB}$ in rodents (Jia and Halpern, 2003; Halpern and Martínez-Marcos, 2003), and their axons course in the vomeronasal nerve to finally reach a limited number of CB-immunoreactive glomeruli in the AOB. No such glomeruli are found in the main olfactory bulb (Jia and
Halpern, 2003). Moreover, the immunostaining for CB identifies the $\mathrm{AOB}$ in anuran and urodele amphibians (Morona and González, 2008).

\section{THE MeA: THE VOMERONASAL AMYGDALA}

In tetrapods, the axons of the projecting cells of the AOB form a tract in the lateral part of the telencephalic hemisphere that reaches specific regions of the amygdala (Halpern and MartínezMarcos, 2003; Brennan and Zufall, 2006). In particular, recent studies in amphibians have shown that the $\mathrm{AOB}$ projects only to the vomeronasal amygdala in the caudal telencephalon, termed the medial amygdala (MeA), by comparison to amniotes (Moreno and González, 2003, 2006, 2007a,b,c).

The localization and subdivisions of the amygdaloid complex in lungfishes has been a matter of debate since early anatomical studies. Thus, the amygdala, as a whole, was not identified on the basis of cytoarchitecture in many studies (Elliot Smith, 1908; Gerlach, 1933; Nieuwenhuys and Meek, 1990; Nieuwenhuys, 1998), or it was proposed to be located in a different region, such as that comprising nucleus preopticus superior in the dorsal half of the telencephalon impar (Rudebeck, 1945), in zones included in the general pallium (Schnitzlein and Crosby, 1967), or in the varyingly interpreted olfactory tubercular cortex (Clairambault and Capanna, 1973). In recent studies, based on immunohistochemical and morphological features, it was proposed that 
lungfishes have three amygdaloid areas (Northcutt, 2008, 2009) fully comparable to those reported in amphibians (Marín et al., 1998; Moreno and González, 2006, 2007c), and subsequent studies with additional markers supported this proposal (González and Northcutt, 2009). In this scenario, it was proposed that within the subpallium and extending into the dorsal portion of the telencephalon impar, a possible homologue of the MeA could be recognized.

In the present study, to evaluate the possible homology of this region with the MeA of tetrapods, we demonstrated that this region is the only one within the telencephalon of Protopterus that expresses the homeodomain transcription factor Orthopedian (OTP), as has been recently demonstrated in tetrapods (Bardet et al., 2008). In addition, the expression of the transcription factors ISL1 and NKX2.1 show a situation identical to that of the MeA in amphibians (González et al., 2002a,b; Moreno et al., 2008). Furthermore, other immunohistochemical features that characterize the MeA in tetrapods, such as substance $P$ and nitric oxide synthase immunoreactivity (Moreno and González, 2003, 2007b), were found in Protopterus. In addition to all these immunohistochemical data, we have demonstrated that the MeA in Protopterus receives the bulk of the AOB projection

\section{REFERENCES}

Bachy, I., and Rétaux, S. (2006). GABAergic specification in the basal forebrain is controlled by the LIM-hd factor Lhx7. Dev. Biol. 291, 218-226.

Bardet, S. M., Martínez-de-la-Torre, M., Northcutt, R. G., Rubenstein, J. L., and Puelles, L. (2008). Conserved pattern of OTP-positive cells in the paraventricular nucleus and other hypothalamic sites of tetrapods. Brain Res. Bull. 75, 231-235.

Baxi, K. N., Doréis, K. M., and Eisthen, H. L. (2006). Is the vomeronasal system really specialized for detecting pheromones? Trends Neurosci. 29, 1-7.

Brennan, P. A., and Zufall, F. (2006). Pheromonal communication in vertebrates. Nature 444, 308-315.

Brinkmann, H., Venkatesh, B., Brenner, S., and Meyer, A. (2004). Nuclear proteincoding genes support lungfish and not the coelacanth as the closest living relatives of land vertebrates. Proc. Natl. Acad. Sci. U.S.A. 101, 4900-4905.

Brox, A., Puelles, L., Ferreiro, B., and Medina, L. (2003). Expression of the genes GAD67 and Distalless-4 in the forebrain of Xenopus laevis confirms a common pattern in tetrapods. J. Comp. Neurol. 461, 370-393.

Carrillo, G. D., and Doupe, A. J. (2004). Is the songbird Area X striatal, pallidal, or both? An anatomical study.J. Comp. Neurol. 473, 415-437.

Clairambault, P., and Capanna, E. (1973). Suggestions for a revision of the cytoarchitectonics of the telencephalon of Protopterus, Protopterus annectens (Owen). Boll. Zool. 40, 149-171.

Date-Ito, A., Ohara, H., Ichikawa, M., Mori, Y., and Hagino-Yamagishi, K.
(2008). Xenopus V1R vomeronasal receptor family is expressed in the main olfactory system. Chem. Senses 33, 339-346.

Derivot, J.H. (1984). Functional anatomy of the peripheral olfactory system of the African lungfish Protopterus annectens Owen: macroscopic, microscopic, and morphometric aspects. Am. J. Anat. 169, 177-192.

Eisthen, H. L. (2000). Presence of the vomeronasal system in aquatic salamanders. Philos. Trans. R. Soc. Lond. B Biol. Sci. 355, 1209-1213.

Eisthen, H.L. (2004). The goldfish knows: olfactory receptor cell morphology predicts receptor gene expression. J. Comp. Neurol. 477, 341-346.

Eisthen, H. L., and Polese, G. (2007). "Evolution of vertebrate olfactory subsystems" in Evolution of Nervous Systems, Vol 2: Non-mammalian Vertebrates, eds J. H. Kaas and T. H. Bullock (Oxford: Academic Press), 355-406.

Elliot Smith, G. (1908). The cerebral cortex in Lepidosiren, with comparative notes on the interpretation of certain features of the forebrain in other vertebrates. Anat. Anz. 33, 513-540.

Erickson, J. R., and Caprio, J. (1984). The spatial distribution of ciliated and microvillous olfactory receptor neurons in the channel catfish is not matched by a differential specificity to amino acid and bile salt stimuli. Chem. Senses 9, 127-141.

Ericson, J., Muhr, J., Jessell, T. M., and Edlund, T. (1995). Sonic hedgehog: a common signal for ventral patterning along the rostrocaudal axis of the neural tube. Int. J. Dev. Biol. 39, 809-816.

and, in turn, is strongly connected with the hypothalamus, giving further support to its homology with the MeA of tetrapod vertebrates (Moreno and González, 2003, 2005b, 2006).

\section{CONCLUSION}

We have thus demonstrated that the lungfish Protopterus dolloi possesses an accessory olfactory system characterized by special receptor cells in the chemosensory nasal organ and a set of brain structures interconnected in the forebrain that were previously described only in tetrapods. This documentation of a pathway relating specific olfactory information through a chain of brain centers (Figure 7) fully comparable to the components of the VNS in tetrapods informs, if not resolves, the debate concerning the origin of the VNS in vertebrates, and it contributes further to our understanding of the first terrestrial vertebrates and their ancestors.

\section{ACKNOWLEDGMENTS}

This work was supported by the National Science Foundation (grant number: IBN-0236018) and the Spanish Ministry of Science and Education (grant numbers: BFU 2006-01014/BFI and BFU2009-12315).

Frontini, A., Zaidi, A. U., Hua, H., Wolak, T. P., Greer, C. A., Kafitz, K. W., Li, W., and Zielinski, B.S. (2003). Glomerular territories in the olfactory bulb from the larval stage of the sea lamprey Petromyzon marinus. J. Comp. Neurol. 465, 27-37.

Gerlach, J. (1933). Über das Gehirn von Protopterus annectens. Anat. Anz. 75, 310-406.

González, A., López, J. M., and Marín, O. (2002a). Expression pattern of homeobox gene Nkx-2.1 in the forebrain of Xenopus laevis during development. Gene Exp. Patterns 1, 181-185.

González, A., López, J. M., SánchezCamacho, C., and Marín, O. (2002b). Regional expression of the homeobox gene NKX2-1 defines pallidal and interneuronal populations in the basal ganglia of amphibians. Neuroscience 114, 567-575.

González, A., Muñoz, A., Muñoz, M. Marín, O., Arevalo, R., Porteros, A., and Alonso, J. R. (1996). Nitric oxide synthase in the brain of a urodele amphibian (Pleurodeles waltl) and its relation to catecholaminergic neuronal structures. Brain Res. 727, 49-64.

González, A., and Northcutt, R. G. (2009). An immunohistological approach to lungfish telencephalic organization. Brain Behav. Evol. 74, 43-55.

Grus, W. E., and Zhang, J. (2006). Origin and evolution of the vertebrate vomeronasal system viewed through systemspecific genes. Bioessays 28, 709-718.

Grus, W. E., and Zhang, J. (2009).Origin of the genetic components of the vomeronasal system in the common ancestor of all extant vertebrates. $\mathrm{Mol}$. Biol. Evol. 26, 407-419.
Hagino-Yamagishi, K., Moriya, K., Kubo, H., Wakabayashi, Y., Isobe, N., Saito, S., Ichikawa, M., and Yazaki, K. (2004). Expression of vomeronasal receptor genes in Xenopus laevis. J. Comp. Neurol. 472, 246-256.

Halpern, M., and Martínez-Marcos, A. (2003). Structure and function of the vomeronasal system: an update. Prog. Neurobiol. 70, 245-318.

Hallström, B. M., and Janke, A. (2009). Gnathostome phylogenomics utilizing lungfish EST sequences. Mol. Biol. Evol. 26, 463-471.

Hansen, A., Anderson, K. T., and Finger, T. E. (2004). Differential distribution of olfactory receptor neurons in goldfish: structural and molecular correlates. $J$. Comp. Neurol. 477, 347-359.

Hansen, A., Rolen, S. H., Anderson, K., Morita, Y., Caprio, J., and Finger, T. E. (2003). Correlation between olfactory receptor cell type and function in the channel catfish. J. Neurosci. 23, 9328-9339.

Hedges, S. B., Hass, C. A., and Maxson, L. R. (1993). Relations of fish and tetrapods. Nature 363, 501-502.

Herbison, A. E., Simonian, S. X., Norris, P. J., and Emson, P. C. (1996). Relationship of neuronal nitric oxide synthase immunoreactivity to $\mathrm{GnRH}$ neurons in the ovariectomized and intact female rat. J. Neuroendocrinol. 8, 73-82.

Jia, C., and Halpern, M. (2003). Calbindin D28K immunoreactive neurons in vomeronasal organ and their projections to the accessory olfactory bulb in the rat. Brain Res. 977, 261-269.

Lazzaro, D., Price, M., de Felice, M., and Di Lauro, R. (1991). The transcription 
factor TTF-1 is expressed at the onset of thyroid and lung morphogenesis and in restricted regions of the foetal brain. Development 113, 1093-1104.

Lee, J., Alrubaian, J., and Dores, R. M. (2006). Are lungfish living fossils? Observation on the evolution of the opioid/orphanin gene family. Gen. Comp. Endocrinol. 148, 306-314.

Lin, X., State, M. W., Vaccarino, F. M., Greally, J., Hass, M., and Leckman, J. F. (1999). Identification, chromosomal assignment, and expression analysis of the human homeodomain-containing gene Orthopedia (OTP). Genomics 60, 96-104.

Marín,O.,Anderson,S.A., and Rubenstein, J. L. (2000). Origin and molecular specification of striatal interneurons. J. Neurosci. 20, 6063-6076.

Marín, O., Smeets, W. J., and González, A. (1998). Basal ganglia organization in amphibians: chemoarchitecture. $J$. Comp. Neurol. 392, 285-312.

Métin, C., Alvarez, C., Moudoux, D., Vitalis, T., Pieau, C., and Molnar, Z. (2007). Conserved pattern of tangential neuronal migration during forebrain development. Development 134, 2815-2827.

Meyer, A., and Dolven, S. I. (1992). Molecules, fossils, and the origin of tetrapods. J. Mol. Evol. 35, 102-113.

Meyer,A., and Wilson, A.C. (1990). Origin of tetrapods inferred from their mitochondrial DNA affiliation to lungfish. J. Mol. Evol. 31, 359-364.

Moreno, N., Domínguez, L., Retaux, S., and González, A. (2008). Islet1 as a marker of subdivisions and cell types in the developing forebrain of Xenopus. Neuroscience 154, 1423-1439.

Moreno, N., and González, A. (2003). Hodological characterization of the medial amygdala in anuran amphibians. J. Comp. Neurol. 466, 389-408.

Moreno, N., and González, A. (2004). Localization and connectivity of the lateral amygdala in anuran amphibians. J. Comp. Neurol. 479, 130-148.

Moreno, N., and González, A. (2005a) Central amygdala in anuran amphibians: neurochemical organization and connectivity. J. Comp. Neurol. 489, 69-91.

Moreno, N., and González, A. (2005b). Forebrain projections to the hypothalamus are topographically organized in anurans: conservative traits as compared with amniotes. Eur. J. Neurosci. 21, 1895-1910.

Moreno, N., and González, A. (2006). The common organization of the amygdaloid complex in tetrapods: new concepts based on developmental, hodological and neurochemical data in anuran amphibians. Prog. Neurobiol. 78, 61-90.

Moreno, N., and González, A. (2007a). Regionalization of the telencephalon in urodele amphibians and its bearing on the identification of the amygdaloid complex. Front. Neurosci. 1: 1; doi: 10.3389/neuro.05/001.2007.

Moreno, N., and González, A. (2007b). Development of the vomeronasal amygdala in anuran amphibians: hodological, neurochemical, and gene expression characterization. J. Comp. Neurol. 503, 815-831.

Moreno, N., and González, A. (2007c). Evolution of the amygdaloid complex in vertebrates, with special reference to the anamnio-amniotic transition. J. Anat. 211, 151-153.

Morona, R., and González, A. (2008). Calbindin-D28k and calretinin expression in the forebrain of anuran and urodele amphibians: further support for newly identified subdivisions. J. Comp. Neurol. 511, 187-220.

Morona, R., and González, A. (2009). Immunohistochemical localization of calbindin-D28k and calretinin in the brainstem of anuran and urodele amphibians. J. Comp. Neurol. 515, 503-537.

Moy-Thomas, J. A., and Miles, R. S. (1971).Palaeozoic Fishes. Philadelphia, PA: W.B. Saunders Co.

Nieuwenhuys, R. (1998). "Lungfishes," in The Central Nervous System of Vertebrates, Vol.2, eds R. Nieuwenhuys, H.J.ten Donkelaar and C. Nicholsonpp (Heidelberg: Springer-Verlag), 936-1006.

Nieuwenhuys, R., and Meek, J. (1990). "The telencephalon of sarcopterygian fishes," in Cerebral Cortex, Vol. $8 \mathrm{~A}$ Comparative Structure and Evolution of Cerebral Cortex Part I, eds E. G. Jones and A. Peters (New York: Plenum Press), 75-106.

Northcutt, R. G. (2008). Forebrain evolution in bony fishes. Brain Res. Bull. 75, 191-205.

Northcutt, R. G. (2009). Telencephalic organization in the spotted African Lungfish, Protopterus dolloi: a new cytological model. Brain Behav. Evol. 73, 59-80.

Puelles, L., and Rubenstein, J. L. (2003). Forebrain gene expression domains and the evolving prosomeric model. Trends Neurosci. 26, 469-476.
Reiner, A., and Northcutt, R. G. (1987). An immunohistochemical study of the telencephalon of the African lungfish, Protopterus annectens.J. Comp. Neurol. 256, 463-481.

Rudebeck, B. (1944). Does an accessory olfactory bulb exist in Dipnoi? Acta Zool. 25, 89-96.

Rudebeck, B. (1945). Contributions to forebrain morphology in Dipnoi. Acta Zool. 26, 9-157.

Sato, Y., Miyasaka, N., and Yoshihara, Y. (2005). Mutually exclusive glomerular innervation by two distinct types of olfactory sensory neurons revealed in transgenic zebrafish. J. Neurosci. 25 4889-4897.

Sato, K., and Suzuki, N. (2001). Wholecell response characteristics of ciliated and microvillous olfactory receptor neurons to amino acids, pheromone candidates and urine in rainbow trout. Chem. Senses 26 1145-1156.

Schnitzlein, H. N., and Crosby, E. C. (1967). The telencephalon of the lungfish, Protopterus. J. Hirnforsch. 9, 105-149.

Schöber, A., Meyer, D. L., and von Bartheld, C. S. (1994). Central projections of the nervus terminalis and the nervus praeopticus in the lungfish brain revealed by nitric oxide synthase. J. Comp. Neurol. 349, 1-19.

Schultze, H. P., and Campbell, K. S. W. (1986). Characterization of the Dipnoi, a monophyletic group. J. Morphol. Suppl. 1, 25-37.

Shepherd, G. M. (2006). Behaviour: smells, brains and hormones. Nature 439, 149-151.

Simonian, S. X., and Herbison, A. E. (1996). Localization of neuronal nitric oxide synthase-immunoreactivity within sub-populations of noradrenergic A1 and A2 neurons in the rat. Brain Res. 732, 247-252.

Smeets, W. J., Alonso, J. R., and González, A. (1997). Distribution of NADPHdiaphorase and nitric oxide synthase in relation to catecholaminergic neuronal structures in the brain of the lizard Gekko gecko. J. Comp. Neurol. 377, 121-141.

Smeets, W. J., and González, A. (2000). Catecholamine systems in the brain of vertebrates: new perspectives through a comparative approach. Brain Res. Rev. 33, 308-379.

Takezaki, N., Figueroa, F., ZaleskaRutczynska, Z., Takahata, N., and Klein, J. (2004). The phylogenetic relationship of tetrapod, coelacanth, and lungfish revealed by the sequences of forty four nuclear genes. Mol. Biol. Evol. 21, 1512-1524.

Takigami, S., Mori,Y., Tanioka, Y., and Ichikawa, M. (2004). Morphological evidence for two types of mammalian vomeronasal system. Chem. Senses 29, 301-310.

Tohyama, Y., Ichimiya, T., KasamaYoshida, H., Cao, Y., Hasegawa, M., Kojima, H., Tamai, Y., and Kurihara, T. (2000) Phylogenetic relation of lungfish indicated by the amino acid sequence of myelin DM20. Brain Res. Mol. Brain Res. 80, 256-259.

Thommesen, G. (1983). Morphology, distribution, and specificity of olfactory receptor cells in salmonid fishes. Acta Physiol. Scand. 117, 241-249.

von Bartheld, C. S., Claas, B., Munz, H., and Meyer, D. L. (1988). Primary olfactory projections and the nervus terminalis in the African lungfish: implications for the phylogeny of cranial nerves. Am. J. Anat. 182, 325-334.

Zaradoya, R., Cao, Y., Hasegawa, M., and Meyer, A. (1998). Searching for the closest living relative(s) of tetrapods through evolutionary analyses of mitochondrial and nuclear data. Mol. Biol. Evol. 15, 506-517.

Zippel, H. P., Sorensen, P.W., and Hansen, A. (1997). High correlation between microvillous olfactory receptor cell abundance and sensitivity to pheromones in olfactory nerve-sectioned goldfish. J. Comp. Physiol. A 180, 39-52.

Conflict of Interest Statement: The authors declare that the research was conducted in the absence of any commercial or financial relationships that could be construed as a potential conflict of interest.

Received: 19 January 2010; paper pending published: 08 February 2010; accepted: 31 July 2010; published online: 01 September 2010.

Citation: González A, Morona R, López JM, Moreno N and Northcutt RG (2010) Lungfishes, like tetrapods, possess a vomeronasal system. Front. Neuroanat. 4:130. doi: 10.3389/fnana.2010.00130

Copyright (c) 2010 González, Morona, López, Moreno and Northcutt. This is an open-access article subject to an exclusive license agreement between the authors and the Frontiers Research Foundation, which permits unrestricted use, distribution, and reproduction in any medium, provided the original authors and source are credited. 